\title{
Photosynthesis and Water Relations in Brazilian Sugarcane
}

\author{
Lauricio Endres*, ${ }^{*}$, José Vieira Silva ${ }^{2}$, Vilma Marques Ferreira ${ }^{1}$, Geraldo Veríssimo De Souza \\ Barbosa $^{1}$
}

${ }^{1}$ Centro de Ciências Agrárias, Universidade Federal de Alagoas, Alagoas, CEP 57072-970, Brazil; ${ }^{2}$ Campus Avançado de Arapiraca, Universidade Federal de Alagoas, Alagoas, CEP 57072-970, Brazil

\begin{abstract}
The expansion of sugarcane (Saccharum spp.) in Brazil has been boosted by the growing demand for bio-fuels all over the world and requires the occupation of new agricultural areas, including regions with unfavorable agro-climatic conditions. This observational study makes an analysis of the relationship between stomatal conductance, gas exchange and photosynthesis in sugarcane fields subject to different ambient conditions and growth phases. It was noted that the stomatal conductance had a much higher control on photosynthesis than on transpiration. Even under high stomatal conductance, photosynthesis maintained a high correlation to it. Sugarcane had an instantaneous water use efficiency of approximately $4.4 \mu \mathrm{mol}$ of fixed $\mathrm{CO}_{2}$ for each mmol of $\mathrm{H}_{2} \mathrm{O}$ expended in transpiration. Lower leaf water potential, besides leading to an internal reduction of $\mathrm{CO}_{2}$, also reduced the instantaneous carboxylation efficiency, indicating that the photosynthesis apparatus was also affected. The variety RB92579, seems to have good water absorption system, because even under low leaf water potential, it maintained a good stomatal conductance, with a higher transpiration and photosynthesis than the others varieties. These results suggest that this variety has a tolerance mechanism to endure rather than avoid drought.
\end{abstract}

Keywords: Stomatal conductance, leaf water potential, instantaneous water use efficiency, Saccharum spp.

\section{INTRODUCTION}

Sugarcane is one of the most viable alternatives for the production of biofuels and renewable energy in the world, notably for tropical countries of great size. In Brazil, where sugarcane is used basically for the production of sugar and ethanol, its yield has been growing and, according to the National Company of Supply [1], the Brazilian sugarcane crop yield for 2006/2007 should be 475.7 million tons, an increase of $10.3 \%$ over the previous harvest.

The productivity of sugarcane is mainly defined by photosynthesis activity, given that the accumulation of carbon skeletons (sugar) in the stem and its size are proportional to the photosynthetic activity during the entire cycle of the crop. Therefore, any biotic or abiotic stress during the whole vegetable phase, mainly in the period of rapid growth, could diminish drastically the yield of sugarcane, as well as affect its potential for regrowth and the longevity of the sugarcane field [2].

Sugarcane has a $\mathrm{C}_{4}$ type metabolism for fixation of carbon, allowing it to be very well adapted to biomass production in tropical regions. However, it depends on favorable environmental conditions to show its maximum potential yield, among them, the adequate availability of water throughout the cycle. Physiologically, sugarcane is economic

*Address correspondence to this author at the Lauricio Endres, Condomínio Chácaras da Lagoa, G-20, Bairro Santa Amélia, Maceió, AL, CEP 57063260, Brazil; Tel: +55 82 32611676; Fax: +55 82 32611351;

E-mail: endres@pq.cnpq.br in water use but, even so, has high water consumption, requiring 250 parts of water to make a dry part of its biomass [3]. A common measure of water use efficiency in sugarcane industry is the yield of cane produced per ML of water for the duration of the crop [4]. Kingston [5] found values of water use efficiency of $12.21 \mathrm{t} \mathrm{ML}^{-1}$ in Australia, while Robertson and Muchow [6] found values from 4.8 to $12.1 \mathrm{t} \mathrm{ML}^{-1}$ of water use efficiency from experiments in Southern Africa, Hawaii and Australia.

Transpiration is primarily regulated by the stomatal opening, and, according to Deng et al. [7], it is the physiological process that is most sensitive to drought stress in most plants. But Inman-Bamber and Smith [4] observed that in sugarcane, the plant growth and leaf extension were more sensitive to drought than stomatal conductance. In general, the stomatal close in response to drought before any change in the water potential or water content of the leaves [8], but also can close when the vapour pressure deficit between the leave and the air increases [9]. And, since photosynthesis is the major source of organic carbon and energy for plant growth and biomass production, the knowledge of the relationship between stomatal conductance and photosynthesis of modern sugarcane genotypes, independent of climate conditions, will be extremely important for understanding the mechanism that leads to the higher productivity of these genotypes.

Water deficit is one of the main obstacles to the expansion of sugarcane in the Brazilian northeast and centerwest and, in some regions, sugarcane cannot be grown without irrigation. Knowing the relationship among stomatal conductance, transpiration and photosynthesis is very important for 
selecting more water efficient or more drought tolerant genotypes by breeding programs.

A more intensive physiological study of the most widely planted varieties in relation to their photosynthesis, transpiration, stomata conductance and leaf water potential will allow selecting a more water use efficient genotypes and more adapted to drought conditions, allowing the occupation of more arid regions. This is the main problem encountered by sugarcane production in the Brazilian northeast, given that the areas available for agriculture with regular rainfall are being used up.

The objective of the study was not to relate the plant gas exchange and the ambient condition, as drought or soil fertility, for example, but to compare different physiological parameters at a specific time in a same plant leaf blade, regardless of ambient conditions. As a result, it can be expected a mathematical model between two parameters in any ambient condition and not only in a specific experimental design.

While the need for observational studies is generally acknowledged, there is, however, serious disagreement on the strength of results to be inferred from individual observational studies [10], but it is largely used in biological studies [11].

Understanding of how gas exchange $\left(\mathrm{CO}_{2}\right.$ and $\left.\mathrm{H}_{2} 0\right)$ and plant water status are related in natural conditions in sugarcane fields can be extremely important for choosing the varieties and the utilization of cultivating practices, mainly irrigation, which may maximize the use of natural resources. This study makes an analysis of the relationship among leaf water potential, stomatal conductance, transpiration and photosynthesis at the same leaf plate of field-grown sugarcane, independent of climate conditions, from some of the most planted varieties in the Brazilian Northeast.

\section{MATERIALS AND METHODS}

This research was an observational study as so did not follow a experimental design, but made an analysis of sugarcane gas exchange measured in plants cultivated in varied soil, climatic and growth stage condition to represent sugarcane cultivation as a whole in natural conditions. Hence, the climatic and soil conditions were not recorded. Measurements were taken in plant and ratoon sugarcane crops at different year seasons (dry and wet season) and at different sugarcane fields along the coastal region, between Coruripe (10 $07^{\prime}$ '58.8' S and 36 $10^{\circ} 33.9^{\prime \prime}$ ) and São Luiz do Quitunde $\left(9^{\circ} 19^{\prime} 04.8^{\prime \prime} \mathrm{S}\right.$ and $\left.35^{\circ} 33^{\prime} 50.5^{\prime} \mathrm{O}\right)$ in the state of Alagoas, Brazil. In all, 28 different sugarcane genotypes with different growth stage were evaluated. At least, four measurements were made in each genotype, and in each ambient condition, resulting in up to 308 readings obtained for each parameter evaluated (see below). In each plant (replication), all parameters were evaluated in the same time. This was important for generating mathematical equations that explain the relationship among parameters in this observational study.

Three of the varieties most cultivated in the region, RB72545, SP79-1011 e RB92579, were chosen to make comparisons. In each plant, all parameters were evaluated in the same time. This was important for generating mathematical equations that explain the relationship among parameters.
The photosynthesis, stomatal conductance and transpiration was measured with a portable infrared gas analyser (IRGA - ADC, model LCi, Hoddesdon, UK). The youngest fully expanded leaf (with ligule shown up) was chosen to seal the gas-exchange cuvette $\left(5.8 \mathrm{~cm}^{2}\right)$ around the leaf at a point approximately $2 / 3$ from the ligule and the tip of the blade. All measurements were made between 8 AM and 2 PM, with photosynthetic photon flux density exceeding 1800 umol m $\mathrm{m}^{-2}$.

Immediately after gas exchange measurements, the leaf water potential $\left(\Psi_{\mathrm{W}}\right)$ was measured using the same leaf blade that the gas-exchange measurements were taken from with a pressure pump (Soil Moisture Equipment, USA).

The data were analyzed by regressions adjusted by the program Table Curve $\mathrm{T}^{\mathrm{TM}}$ of AISN Software.

\section{RESULTS AND DISCUSSION}

Significant advances in the study of stress physiology in crops have been made by correlations between environmental factors and the crop response to it and cultivation practices. In the case of this study, we made and analyses of the correlation among conductance, transpiration and photosynthesis, regardless of the environmental conditions and the physiological state (Fig. 1).

At a more detailed level, the stomata had a strong influence over transpiration $(\mathrm{R} 2=0.89$, Fig. 1A). When the stomatal conductance were divided into two groups, for conductance lower than $0.10 \mathrm{~mol} \mathrm{~m}^{-2} \mathrm{~s}^{-1}$, its control over transpiration was linear and with higher correlation coefficient $\left(\mathrm{Y}=0.417+39.870 \mathrm{X}, \mathrm{R}^{2}=0.93\right)$. For stomatal conductance greater than $0.10 \mathrm{~m}^{-2} \cdot \mathrm{s}^{-1}$, the control of stomata over transpiration was decouple and did not occur in a direct and proportional way $\left(Y=8.30-0.44 / X, R^{2}=0.47\right)$. In this case, the variability of transpiration response to the stomatal opening could be in consequence of the variability of vapour pressure deficits between the leaf and the atmosphere, which could significantly influence the leaf transpiration $[4,12,13]$. On the other hand, this could also occur due to the variations of water vapour exchange as a function of the degree of opening, size and stomatal pore depth and arrangement and density of the stomata $[14,15]$.

The photosynthetic activity of sugarcane depends greatly on stomatal conductance (Fig. 1B). This was more evidenced for stomatal conductance less than $0.10 \mathrm{~mol} \mathrm{~m}^{-2} \mathrm{~s}^{-1}$, where the photosynthetic response of sugarcane was linear $\left(\mathrm{Y}=0.55+146.534 \mathrm{X}, \mathrm{R}^{2}=0.92\right)$. As the stomatal conductance was increased, photosynthesis began to respond exponentially $\left(\mathrm{Y}=-29.694+83.03 \mathrm{X}^{0.2774}, \mathrm{R}^{2}=0.74\right)$. Du et al. [16] also showed that the reduction of stomatal conductance, in consequence of moderate drought stress, is the main factor that reduces photosynthesis in sugarcane.

When we established a correlation between transpiration and photosynthetic activity we found it was positive and adjusted itself to a linear regression model $(\mathrm{R}=0.91$, Fig. 1C), mainly under a low transpiration rate ( $\mathrm{Y}=-$ $0.4723+3.694 \mathrm{X}, \mathrm{R}=0.91$ ) with transpiration less than $5 \mathrm{mmol}$ $\mathrm{m}^{-2} \mathrm{~s}^{-1}$, possibly reflecting the control of gas exchange by the stomata (Fig. 1A, 1B). With a high rate of transpiration, the correlation with photosynthesis rate was highly variable $(\mathrm{Y}=4.9148+3.577 \mathrm{X}, \mathrm{R}=0.624)$. This behavior reinforces the 
idea that, as the stomatal opening increases, control over the water vapour and $\mathrm{CO}_{2}$ exchanges through the stomatal pores is lost, and it is not possible to make precise inferences about the efficiency of $\mathrm{CO}_{2}$ fixation by the photosynthetic apparatus [17].

On the other hand, this variance of photosynthesis, when transpiration was greater than $5.0 \mathrm{mmol} \mathrm{m}^{-2} \mathrm{~s}^{-1}$, suggests a great genotype variability of the photosynthetic activities under high rates of transpiration. The gas exchange mechanisms, in special photosynthesis, governed by the stomata, and associated with morphological characteristics, are of fundamental importance for the tolerance of the plant to water deficit and could vary significantly among genotypes. However, these correlations are not taken into consideration in plant breeding programs, since this information generally includes only commercial varieties [4].

The relation between photosynthesis and transpiration represents the instantaneous water use efficiency $\left(\mathrm{WUE}_{\mathrm{i}}\right)$ (Fig. 1C). The angular coefficient of the linear relation showed a value close to $4.4 \mu \mathrm{mol} \mathrm{CO}_{2}$ fixed for each mmol of $\mathrm{H}_{2} \mathrm{O}$ spent in transpiration qualified at several vapour pressure deficit (VPD), with mean VPD of $4,4 \mathrm{kPa}$; in other words, for each gram of fixed $\mathrm{CO}_{2}, 92$ grams of water were spent. The $\mathrm{WUE}_{\mathrm{i}}$ was also strongly negative correlated to VPD (Fig. 1C, insert), while the correlation of VPD with transpiration or photosynthesis was weak (date not shown). Similar results of $\mathrm{WUE}_{\mathrm{i}}$ were noted by $\mathrm{Vu}$ et al. [18], who found values between 3.8 and $5.8 \mu \mathrm{mol} \mathrm{mmol}{ }^{-1}$, according to the age of the leaf of the sugarcane variety CP73-1547. Other C4 species, Andropogon gerardii and Sorghastrum nutans, showed values between 4.3 and $5.3 \mu_{\mathrm{mol}} \mathrm{mmol}^{-1}$, well above the values seen for $\mathrm{C} 3$ species such as Aster ericoides, Echinacea angustifolia, Amorpha canescens, Lespedeza capitata and Psoralea tenuiflora, the values for which were between 1.7 and $2.2 \mu \mathrm{mol} \mathrm{mmol}{ }^{-1}$ under the same environmental conditions [19].

These values were instantaneous, however, do not reflect the WUE behavior during the crop cycle. The $\mathrm{WUE}_{\mathrm{i}}$ is highly variable during the day and the season of the year. The "Valência" oranges have a value between 1.8 and 2.2 in the summer and 3.8 and 5.2 in the winter, depending on the time of day and the rootstock used [20]. In Chamaecytisus proliferus, a shrub of the Canary Islands, the $\mathrm{WUE}_{\mathrm{i}}$ varies between less than 1.0 to $4.0 \mu \mathrm{mol} \mathrm{mmol}{ }^{-1}$, depending on the time of day and season of the year. In our study, the WUE was not measured during the whole day, but only from $8 \mathrm{AM}$ to $2 \mathrm{PM}$, but the measurements were made under different environmental conditions (different VPD), and using several genotypes; thus the value of $\mathrm{WUE}_{\mathrm{i}}$ of $4.4 \mu \mathrm{mol} \mathrm{mmol}^{-1}$ may be considered representative for sugarcane.

It is interesting to note that the stomatal conductance had a much better control over photosynthetic activity than over transpiration (Figs. 1A, 1B). This suggests that the breeding programs intended to improve sugarcane productivity, regardless of the water deficit, should give preference to genotypes with a higher stomatal conductance, independent of its transpiration rate. Besides, for greater stomatal conductance, greater amplitude of response in photosynthetic activity occurred in relation to the stomatal conductance (Fig. 1B), which would facilitate the selection of more productive genotypes.
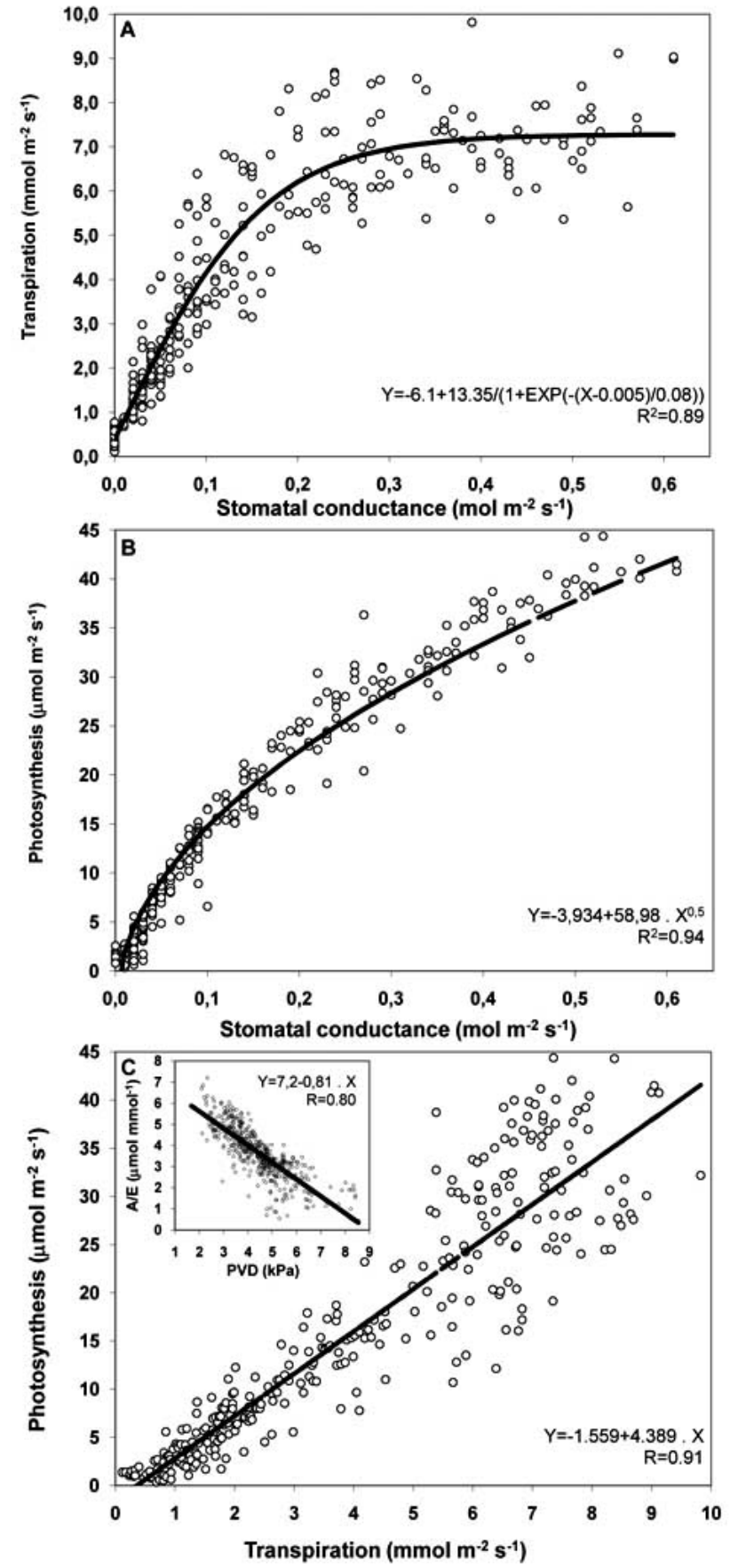

Fig. (1). Relationship between stomatal conductance (A), transpiration (B), and photosynthesis in 28 sugarcane genotypes, $n=360$.

The water status of the leaf is essential for the maintenance of photosynthetic activity. In sugarcane, even if the stomatal conductance showed a high positive and direct correlation with photosynthesis, low variation of the leaf water potential occurs with photosynthetic activity above $20 \mu \mathrm{mol}$ $\mathrm{m}^{-2} \mathrm{~s}^{-1}$ (Fig. 2A). Similar results were reported by Meinzer et al. [21] in sugarcane, where the stomatal conductance was seen to reduce in response to water depletion in the soil without significant changes in the soil water potential. 
On the other hand, when the leaf water potential was about $-1.5 \mathrm{MPa}$, photosynthetic rates were less than $20 \mu \mathrm{mol}$ $\mathrm{m}^{-2} \mathrm{~s}^{-1}$. Studies showed that the water potential of sugarcane at midday without water limitation is $-1.0 \mathrm{MPa}[22,23]$ and is $-1.5 \mathrm{MPa}$ for sugarcane under water deficit [22]. These results suggest that the leaf water potential may be considered a good indicator of the water status of the plant that maximizes its photosynthetic activity.

The internal leaf $\mathrm{CO}_{2}$ concentrations seems to be limited by photosynthetic activity between 5 and $25 \mu \mathrm{mol} \mathrm{m} \mathrm{m}^{-2} \mathrm{~s}^{-1}$ (Fig. 2B), which corresponds to stomatal conductance below $0.3 \mathrm{~mol} \mathrm{~m}^{-2} \mathrm{~s}^{-1}$ (Fig. 1B) at the lowest photosynthetic activity. Meinzer et al. [24] and Saliendra et al. [25] found a $\mathrm{Ci} / \mathrm{Ca}$ ratio relatively constant under adverse environmental conditions for sugarcane. With the photosynthetic rate below $5.0 \mu \mathrm{mol} \mathrm{m} \mathrm{m}^{-2} \mathrm{~s}^{-1}$, an increase in the $\mathrm{Ci} / \mathrm{Ca}$ ratio occurred (Fig. 2B). These results probably indicate that direct damage on the photosynthetic apparatus had occurred, so that no more assimilation of $\mathrm{CO}_{2}$ had taken place. At the same time, along with the reduction of photosynthetic activity a reduction in the instantaneous carboxylation efficiency was noted (Fig. 2C). Du et al. [16] noted that in sugarcane under moderate stress (leaf water potential down to $-0.9 \mathrm{MPa}$ ), the reduction in photosynthesis was due to the reduction of stomatal conductance. However, when stress became severe (leaf water potential around -1.2 $\mathrm{MPa}$ ), the levels of pyruvate and the activity of the enzyme pyruvate orthophosphate dikinase fell drastically, demonstrating that there was also a metabolic injury.

The RB72454, SP79-1011 and RB92579 varieties come from breedings made in different years and are still used today as standards for most of the sugarcane breeding programs in Brazil. Currently, due to its high productivity under rainfed conditions, the RB92579 variety is one of the most planted varieties in Northeastern Brazil. With the intention of better understanding the behavior of these varieties under rainfed conditions, a comparative study was made of the relations between the stomatal conductance and photosynthesis and between transpiration and photosynthesis in these three varieties (Fig. 3).

The RB92579 variety had the greatest transpiration rate among the three varieties under high stomatal conductance (Fig. 3A). The RB72454 variety had the highest transpiration rate under low stomatal conductance (Fig. 3B). However, with stomatal conductance above 0.3 and $0.4 \mathrm{~mol} \mathrm{~m}^{-2} \mathrm{~s}^{-1}$, this variety started to show lower rates of transpiration (Fig. 3A). Silva et al. [26] showed that the RB92579 variety has practically double the root density than SP79-1011 and RB72454. The higher transpiration rate and root density of RB92579 may be responsible for its good productivity in drought conditions, as observed in drought years by farmers. In the same conditions, the SP791011 variety has the characteristic of rolling up the leaf [27], which helps it to reduces transpiration independent of the stomatal conductance (Fig. 3B). According to SMIT and SINGELS [23], a rapid stomatal closing, rolling up of leaves and osmotic adjustment are possible mechanisms for drought tolerance in sugarcane.

It is possible that the greater capacity for water intake of the RB92579 variety is due to the greater hydraulic conductivity of its roots in relation to the other varieties, since this characteristic is variable among the sugarcane genotypes
[28]. These authors found a good correlation between hydraulic conductivity and anatomical characteristics in sugarcane. They concluded that the hydraulic conductivity of the H69-8235 variety, considered to have good tolerance to drought and saline stress, had a broader metaxylem, which facilitates axial conductance, and a higher ratio between the stele and cortex indicating higher radial conductance. This suggests that the hydraulic conductivity is associated with simple anatomical characteristics that could be used in breeding programs with the intention of selecting genotypes that are more tolerant to the water deficit.
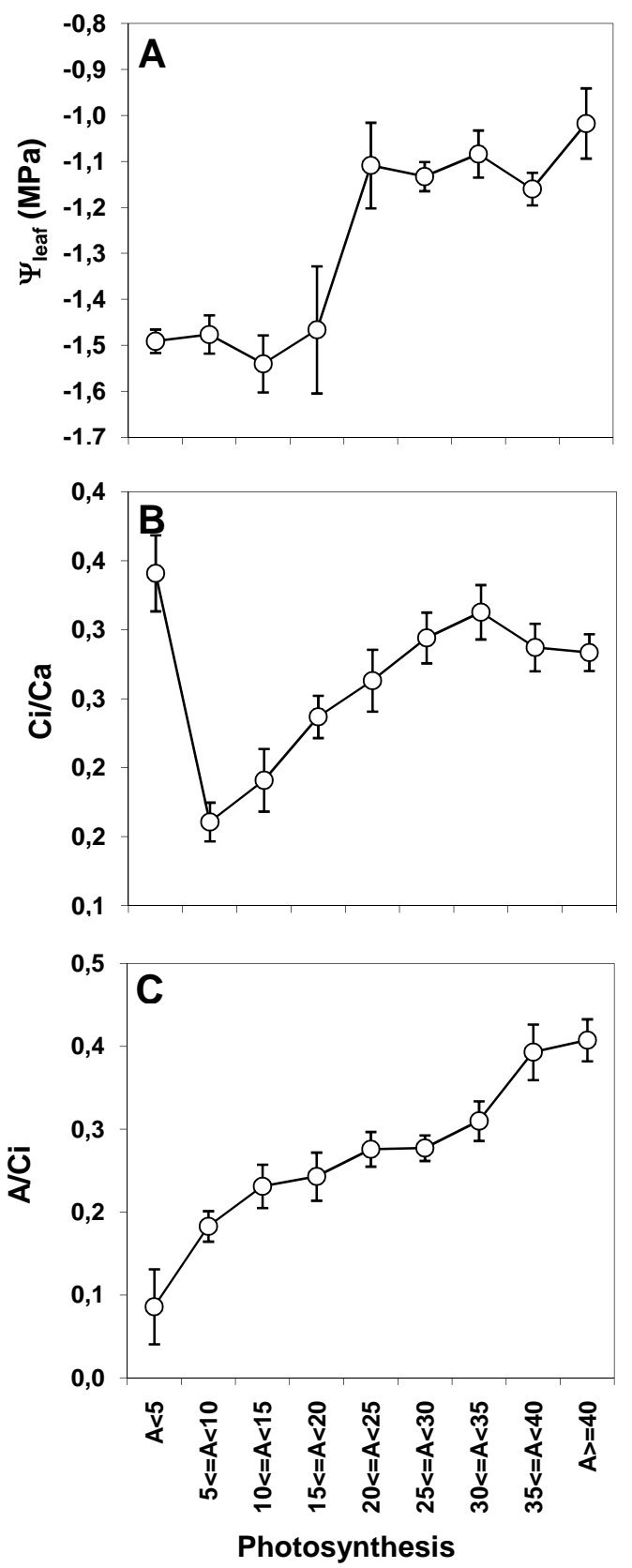

Fig. (2). Leaf water potential $\left(\left(\Psi_{\text {leaf }}\right)\right.$, relationship between internal and external $\mathrm{CO}_{2}$ concentration $(\mathrm{Ci} / \mathrm{Ca})$ and instantaneous carboxylation efficiency $(\mathrm{A} / \mathrm{Ci})$ related to photosynthesis $(\mathbf{A})$ classified in: $A<5, n=76,5 \leq A \geq 10, n=51,10 \leq A \geq 15, n=31,15 \leq A \geq 20, n=31$, $21 \leq A \geq 25, n=24,25 \leq A \geq 30, n=25,30 \leq A \geq 35, n=25,35 \leq A \geq 40, n=24$, $\mathrm{A} \geq 40, \mathrm{n}=09$. 
The RB92579 and RB72454 varieties have the highest photosynthetic rates under wide stomatal conductance range (Figs. 3C and 3D). This fact could be related to the greater density of stoma of these two varieties in relation to SP791011 [27]. And, under drought stress, the rolling up of leaves of the SP79-1011 variety may make the diffusion of $\mathrm{CO}_{2}$ more difficult to the interior of the leaf, lowering the photosynthetic rate.

The RB72454 variety had greater instantaneous efficiency in water usage (Fig. 3E). However, under low transpi-
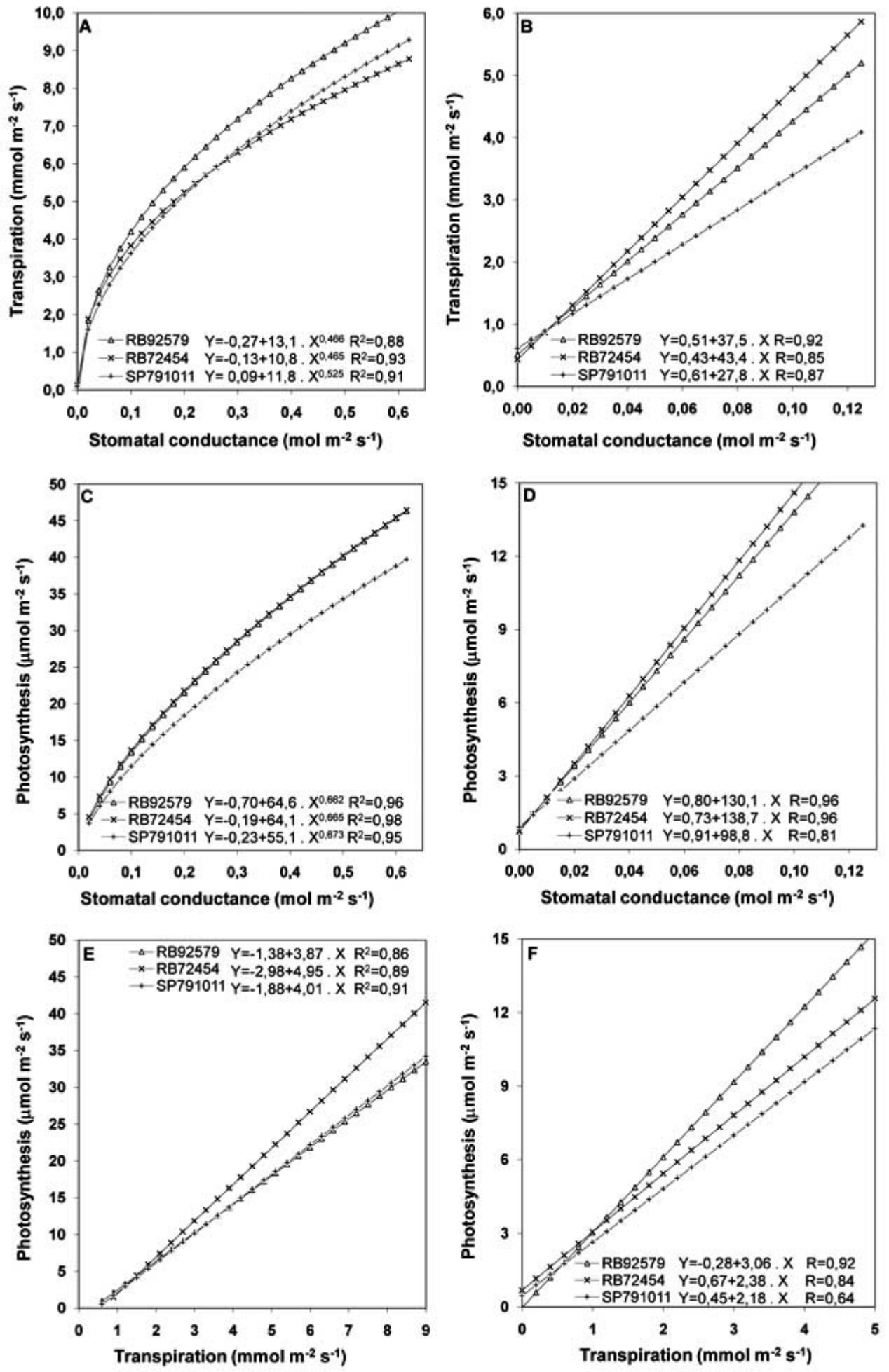

Fig. (3). Relationship between stomatal conductance, transpiration and photosynthesis of the sugarcane varieties. Whole data (A, C, E), stomatal conductance below $0.1 \mathrm{~mol} \mathrm{~m}^{-2} \mathrm{~s}^{-1}(\mathbf{B}, \mathbf{D})$, transpiration below $5.0 \mathrm{mmol} \mathrm{m} \mathrm{s}^{-1}(\mathbf{F}), \mathrm{RB} 92579(\mathrm{n}=40), \mathrm{RB} 72454(\mathrm{n}=28)$ e SP79-1011 $(n=29)$. 
ration, the RB92579 variety was more efficient (Fig. 3F). The fact that the RB92579 variety has good water adsorption and is very efficient in water usage, mainly under water deficit, could partly explain its high productivity under drought conditions.

Leaf water potential measures water tension in the leaf xylem. By this means, one gets an idea of the leaf capacity to extract water from the soil. In most species, the stomata are very sensitive to variations in leaf water potential [29-32]. Of the three varieties of sugarcane, the stomatal conductance and the photosynthetic rate of the RB92579 were found to be less sensitive to variations in the leaf water potential, with a slope coefficient of the linear relation of $0.37 \mathrm{~mol} \mathrm{~m}^{-1} \mathrm{~s}^{-1}$ $\mathrm{MPa}^{-1}$ and $33.5 \mu \mathrm{mol} \mathrm{m} \mathrm{s}^{-1} \mathrm{MPa}^{-1}$, respectively (Figs. 4A and 4B).

However, all varieties showed a similar transpiration response as a function of leaf water potential (Fig. 4C), between 8 and $9 \mathrm{mmol} \mathrm{m}^{-1} \mathrm{~s}^{-1} \mathrm{MPa}^{-1}$, the RB92579 variety had the capacity to maintain a higher transpiration rate in relation to the others under the same water potential. For example, on fixing a leaf water potential at $-1,5 \mathrm{MPa}$, the RB92579, RB72454 and SP-79-1011 varieties showed transpiration rates of $3.44,2.25$ and $0.35 \mathrm{mmol} \mathrm{m}^{-2} \mathrm{~s}^{-1}$, respectively (Fig. 4C). Similarly, at the same leaf water potential $(-1,5 \mathrm{MPa})$, the varieties showed stomatal conductance of $0.108,0.061 \mathrm{e}$ $0.0 \mathrm{~mol} \mathrm{~m}^{-2} \mathrm{~s}^{-1}$ and photosynthetic rates of $11.8,7.2$ and -1.0 $\mu \mathrm{mol} \mathrm{m} \mathrm{m}^{-2} \mathrm{~s}^{-1}$, respectively. These results suggest that the RB92579 variety has a lower leaf osmotic potential than the others, facilitating water conduction from the soil to the leaves and resulting in greater stomatal conductance and photosynthetic rate.

The difference in response of the RB92579 variety to leaf water potential suggests that this variety has a strategy different from the other two varieties for resisting to drought by an reduction in leaf water potential without greatly reducing stomatal conductance and photosynthesis (Figs. $\mathbf{4 A}$ and $\mathbf{4 B}$ ), besides having a more developed root system [26]. Thus, RB92579 succeeds in extracting more water from the soil in order to maintain its high transpiration rate (Fig. 3A), without greatly reducing the photosynthetic activity.

While the RB72454 and SP791011 varieties showed a rapid response of the stomata to the reduction in leaf water potential and the SP791011 by having a characteristic of rolling up of leaves [27], making them less tolerant to drought but having greater control over water economy.

\section{CONCLUDING DISCUSSION}

Inman-Bamber (1986), cited by Inman-Bamber and Smith [4], studying varieties of sugarcane in South Africa, found that the variety most tolerant to drought stress practically closed almost all the stomata when leaf water potential reached -1.4 $\mathrm{MPa}$, while most sensitive varieties this happened when leaf water potential reached $-1,8 \mathrm{MPa}$. These results led the author, and Inman-Bamber and Smith [4] in their review, to conclude that the most tolerant sugarcane varieties to water deficit tend to avoid water loss by closing the stomata. However, the opposite mechanism seems to be present in the RB92579 variety, which has a higher root density [26] allowing it to keep the stomatal open over a broad range of leaf water potential, suggesting that this variety has mechanism allowing it to withstand the water deficit instead of avoiding it, as Inman-Bamber and Smith [4] suggest. It would be interesting then, to place these varieties in the same experimental field to better test and compare their drought tolerance. The combination of these characteristics in breeding programs perhaps may be a good way of improving the crop tolerance to water deficit.

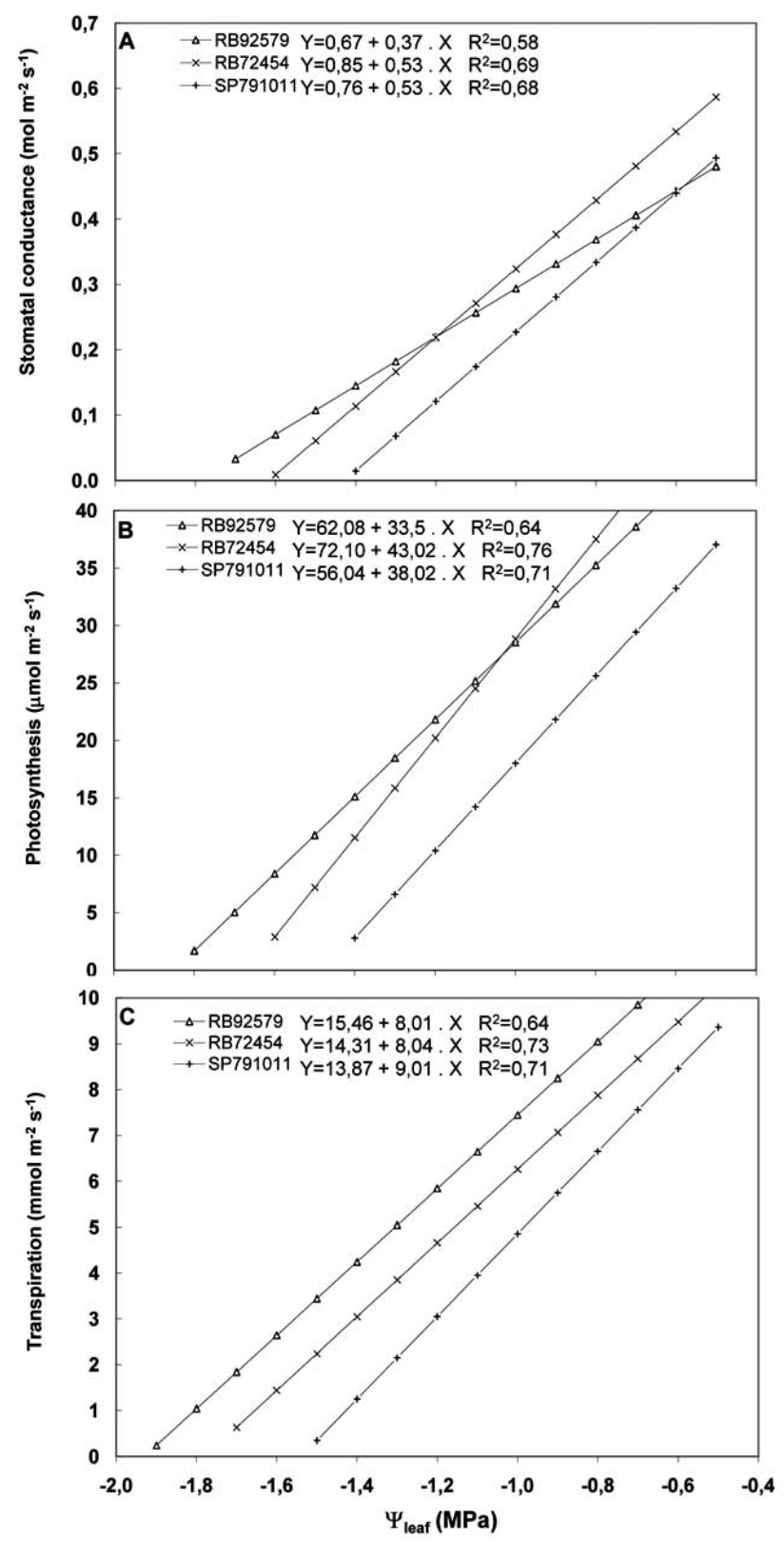

Fig. (4). Relationship between leaf water potential $\left(\Psi_{\text {leaf }}\right)$ and stomatal conductance $(\mathbf{A})$, photosynthesis $(\mathbf{B})$ and transpiration $(\mathbf{C})$ in sugarcane varieties RB92579 ( $\mathrm{n}=40), \operatorname{RB} 72454(\mathrm{n}=28)$ e SP79$1011(n=29)$.

\section{ACKNOWLEDGEMENTS}

We acknowledge the Research Foundation for the State of Alagoas (FAPEAL) and the National Council for Scien- 
tific and Technological Development $(\mathrm{CNPq})$ for financial support.

\section{REFERENCES}

[1] CONAB (Companhia Nacional de Abastecimento), 2007. Disponível em: <http://www.conab.gov.br>. Acesso em 15 jan. 2007, 16: $30: 25$.

[2] Castro PRC, Zambon S, Sansigolo MA, Beltrame JA, Nogueira MCS. Ação comparada de Ethrel, Fuzilade e Roundup, em duas épocas de aplicação, na maturação e produtividade da cana-deaçúcar SP 70-1143. Rev de Agric 2002; 77: 23-38.

[3] Van Dillewijn C. Botany of sugarcane. Waltham: Chronica Botanica 1952; p. 371

[4] Inman-Bamber NG, Smith DM. Water relations in sugarcane and response to water deficits. Field Crops Res 2005; 92: 185-202.

[5] Kingston G. Benchmarking yield of sugarcane from estimates of water use. Proc Austr Soc Sug Cane Technol 1994; 16: 201-9.

[6] Robertson MJ, Muchow RC. Future research challenges for efficient crop water use in sugarcane production. Proc Austr Soc Sug Cane Technol 1994; 16: 193-200.

[7] Deng X, Hu, ZA, Wang HX, Wen XG, Kuang TY. A comparison of photosynthetic apparatus of the detached leaves of the resurrection plant Boea hygrometrica with its con-tolerant relative Chirita hererotrichia in response to dehydration and rehydration. Plant Sci 2003; 165: 851-61.

[8] Socias X, Correia MJ, Chaves M, Medrano H. The role of abscisic acid and water relations in drought responses of subterranean clover. J Exp Bot 1997; 48: 1281-8.

[9] Oren R, Sperry JS, Katul GG, et al. Survey and synthesis of intraand interspecific variation in stomatal sensitivity to vapour pressure deficit. Plant Cell Environ 1999; 22: 1515-26.

[10] Mcdermott JJ. Progress in analytic methods - more sophistication or back to basics?, Prev Veter Med 1995; 25: 121-33.

[11] Scheider SM, Gurevitch J, Eds. Design and analysis of ecological experiments. 2nd ed., Oxford: Oxford University 2001; p. 415.

[12] Leonardi C, Guichard S, Bertin N. High vapour pressure deficit influences growth, transpiration and quality of tomato fruits. Sci Horticult 2000; 84: 285-96.

[13] González-Rodríguez AM, Martín-Olivera A, Morales D, Jiménez MS. Physiological responses of tagasaste to a progressive drought in its native environment on the Canary Islands. Environ Exp Bot 2005; 53: 195-204.

[14] Larcher W. Ecofisiologia vegetal. São Carlos, SP, Brazil: Editora Rima 2000; p. 531.

[15] Marenco RA, Lopes NF. Fisiologia Vegetal: Fotossíntese, Respiração, Relações Hídricas e Nutrição Mineral. Viçosa, MG, Brazil: Editora UFV 2005; p. 451.

[16] Du YC, Nose A, Wasano K, Uchida Y. Responses to water stress of enzyme activities and metabolite levels in relation to sucrose and starch synthesis, the Calvin cycle and the C4 pathway in sugarcane (Saccharum sp.) leaves. Austr J Plant Physiol 1998; 25: 253-60.
[17] Angelocci LR . Água na Planta e Trocas Gasosas/Energéticas com a Atmosfera: Introdução ao tratamento biofísico. Piracicaba, MG, Brazil: Edição do Autor 2002; p. 272.

[18] Vu JCV, Allen JR LH, Gesch RW. Up-regulation of photosynthesis and sucrose metabolism enzymes in young expanding leaves of sugarcane under elevated growth $\mathrm{CO}_{2}$. Plant Sci 2006; 171: 123-31

[19] Nipperta JB, Fayb PA, Knapp AK. Photosynthetic traits in C3 and $\mathrm{C} 4$ grassland species in mesocosm and field environments. Environm. Exp Bot 2007; 60: 412-20.

[20] Machado EC, Medina CL, Gomes MMA, Habermann G. Variação sazonal da fotossíntese, condutância estomática e potencial da água na folha de laranjeira 'valência'. Sci Agric 2002; 59: 53-8.

[21] Meinzer FC, Grantz DA, Smit B. Root signals mediate coordination of stomatal and hydraulic conductance in growing sugarcane. Austr J Plant Physiol 1991; 18: 329-38.

[22] Roberts J, Nayamuth RA, Batchelor CH, Soopramanien GC. Plantwater relations of sugarcane (Saccharum officinarum L.) under a range of irrigated treatments. Agric Water Manag 1990; 17: 95115.

[23] Smit MA, Singels A. The response of sugarcane canopy development to water stress. Field Crops Res 2006; 98: 91-7.

[24] Meinzer FC, Plaut Z, Saliendra NZ. Carbon isotope discrimination, gas exchange, and growth of sugarcane cultivars under salinity. Plant Physiol 1994; 104: 521-6.

[25] Saliendra NZ, Meinzer FC, Perry M, Thom M. Associations between partitioning of carboxylase activity and bundle sheath leakiness to $\mathrm{CO}_{2}$, carbon isotope discrimination, photosynthesis, and growth in sugarcane. J Exp Bot 1996; 47: 907-14.

[26] Silva JV, Mello-Ivo WMP, Gonçalves ER, Leão VL, Costa MMS, Pereira FRS. Distribuição do sistema radicular em variedades de cana-de-açúcar (Saccharum officinarum). In: 10 ${ }^{\text {th }}$ Brazilian Conference of Plant Physiology and $12^{\text {th }}$ Latin American Conference of Plant Physiology, Recife. CD-ROM 2005

[27] Silva JV, Costa MMS, Gonçalves ER, Vieira RCS, Endres L, Ferreira VM. Caracterização foliar de cana-de-açúcar. In: $10^{\text {th }}$ Brazilian Conference of Plant Physiology and $12^{\text {th }}$ Latin American Conference of Plant Physiology, Recife. CD-ROM 2005.

[28] Saliendra NZ, Meinzer FC. Genotypic, developmental and droughtinduced differences in root hydraulic conductance of contrasting sugarcane cultivars. J Exp Bot 1992: 43: 1209-17

[29] Mielke MS, Oliva MA, Barros NF, Penchel RM, Martinez CA, Almeida AC. Stomatal control of transpiration in the canopy of a clonal Eucalyptus grandis plantation. Trees 1999; 13: 152-60.

[30] Liu F, Andersen MN, Jacobsen SE, Jensen CR. Stomatal control and water use efficiency of soybean (Glycine max L. Merr.) during progressive soil drying. Environ Exp Bot 2005; 54: 33-40.

[31] Agele S, Cohen SS, Assouline S. Hydraulic characteristics and water relations of net house-grown bell pepper as affected by irrigation regimes in a Mediterranean climate 2006; 57: 226-35.

[32] Hattori $\mathrm{T}$, Sonobe $\mathrm{K}$, Inanaga $\mathrm{S}$, et al. Short term stomatal responses to light intensity changes and osmotic stress in sorghum seedlings raised with and without silicon. Environ Exp Bot 2007; 60: $177-82$.

This is an open access article licensed under the terms of the Creative Commons Attribution Non-Commercial License (http://creativecommons.org/licenses/ by-nc/3.0/) which permits unrestricted, non-commercial use, distribution and reproduction in any medium, provided the work is properly cited. 